\title{
Die lewe en werk van Frances Young (1939-) en Dorothee Sölle (1929-2003):'n Leksikografiese bydrae tot Reformasie 500
}

\begin{tabular}{|c|c|}
\hline \multicolumn{2}{|c|}{$\begin{array}{l}\text { Authors: } \\
\text { Tanya van } W_{y k} k^{1} \\
\text { Neltjie C. van } W y k^{2}\end{array}$} \\
\hline \multicolumn{2}{|c|}{$\begin{array}{l}\text { Affiliations: } \\
\text { 'Department of Dogmatics } \\
\text { and Christian Ethics, Faculty } \\
\text { of Theology, University of } \\
\text { Pretoria, South Africa }\end{array}$} \\
\hline \multicolumn{2}{|c|}{$\begin{array}{l}{ }^{2} \text { Department of Nursing } \\
\text { Science, Faculty of Health } \\
\text { Sciences, University of } \\
\text { Pretoria, South Africa }\end{array}$} \\
\hline \multicolumn{2}{|c|}{$\begin{array}{l}\text { Research Project } \\
\text { Registration } \\
\text { Project Leader: T. van Wyk } \\
\text { Project Number: } 21531452\end{array}$} \\
\hline \multicolumn{2}{|c|}{$\begin{array}{l}\text { Description: } \\
\text { Project Description: This } \\
\text { research is part of the } \\
\text { project, 'The legacy of the } \\
\text { 16th century Reformation } \\
\text { and the South-African } \\
\text { democratic ideal', directed by } \\
\text { Dr Tanya van Wyk, } \\
\text { Department of Dogmatics } \\
\text { and Christian Ethics, Faculty } \\
\text { of Theology, University of } \\
\text { Pretoria. }\end{array}$} \\
\hline \multicolumn{2}{|c|}{$\begin{array}{l}\text { Corresponding author: } \\
\text { Tanya van Wyk, } \\
\text { tanya.vanwyk@up.ac.za }\end{array}$} \\
\hline \multicolumn{2}{|c|}{$\begin{array}{l}\text { Dates: } \\
\text { Received: } 09 \text { May } 2017 \\
\text { Accepted: } 04 \text { June } 2017 \\
\text { Published: } 27 \text { July } 2017\end{array}$} \\
\hline \multicolumn{2}{|c|}{$\begin{array}{l}\text { How to cite this article: } \\
\text { Van Wyk, T. \& Van Wyk, N.C., } \\
\text { 2017, 'Die lewe en werk van } \\
\text { Frances Young (1939-) en } \\
\text { Dorothee Sölle (1929-2003): } \\
\text { 'n Leksikografiese bydrae tot } \\
\text { Reformasie 500', HTS } \\
\text { Teologiese Studies/ } \\
\text { Theological Studies 73(1), } \\
\text { a4645. https://doi. } \\
\text { org/10.4102/hts.v73i1.4645 }\end{array}$} \\
\hline \multicolumn{2}{|l|}{ Read online: } \\
\hline 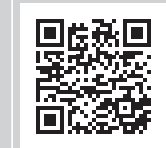 & $\begin{array}{l}\text { Scan this QR } \\
\text { code with your } \\
\text { smart phone or } \\
\text { mobile device } \\
\text { to read online. }\end{array}$ \\
\hline
\end{tabular}

\section{Authors:}

Affiliations:

${ }^{1}$ Department of Dogmatics Christian Ethics, Faculty of Theology, University of

${ }^{2}$ Department of Nursing Science, Faculty of Health Sciences, University of

Research Project

Project Leader: T. van Wyk

Description

Project Description: This project, 'The legacy of the 16th century Reformation

Dr Tanya van Wyk

Department of Dogmatics Pretoria.

Corresponding author: Tanya van Wyk

Dates:

Accepted: 04 June 2017

How to cite this article: Van Wyk, T. \& Van Wyk, N.C 2017, 'Die lewe en werk van (1939-) en 'n Leksikografiese bydrae tot Reformasie 500', HTS a4645. https://doi. org/10.4102/hts.v73i1.4645

to read online.
The contribution of two women to the Reformed heritage: The life and work of Frances Young (1939-) and Dorothee Sölle (1929-2003). This article is a lexicographical overview of the life and work of two specific women, Frances Young and Dorothee Sölle. The purpose of this is to highlight the reformed character of their respective theologies. Both are characterised by reflection on and reaction to the fragility of human life and the brokenness of the human condition. They are among the 'cloud of witnesses' that bear testimony to the impact and heritage of the Reformation.

\section{Inleiding}

Dit is nie moeilik om te bewys dat die Reformasie en die gepaardgaande beweging wat gedurende die sestiende eeu ontstaan het, 'n langdurige en standhoudende invloed op die Christelike teologie gehad het nie. Die erfenis van die Reformasie het weergalm en neerslag gevind in verskillende teologieë wat oor die grense van kontinente, kontekste, sosiaalekonomiese en politieke omstandighede, geslagte, etnisiteit en gender strek. Versprei oor tyd en plek, het talle teoloë telkens getuig oor die impak en die erfenis van Reformatoriese teologie. Vroue is deel van hierdie 'wolk van getuies'. Om dié rede word die teologiese bydraes van twee vroue leksikografies aan die orde gestel.

Teologiese nadenke oor die gebrokenheid van die menslike lewe bind hierdie twee vroue aan mekaar. Frances Young maak insiggewende bydraes oor menslike gestremdheid. Haar erg gestremde seun het hierdie patroloog gedwing om met ander oë na die Nuwe Testament en die vroeë kerklike teologie te kyk. As predikant van die Metodistekerk handhaaf sy 'n tipies Lutherse benadering tot die eksistensiële nood van mense met gestremdhede. 'n Theologia crucis bly vir haar die mees sinvolle benadering tot gestremdheid. Dorothee Sölle het op haar beurt belangrike bydraes gelewer tot die onvolmaaktheid van die menslike samelewing. Sy het as teoloog weerstand gebied teen sosiale onreg en haar beywer vir 'n samelewing met groter menslikheid en medemenslikheid. Beide hierdie vroue verdien om in die jubileumjaar van die Reformasie (2017) gedenk te word. Hulle is totaal verskillende persoonlikhede met verskillende benaderings tot die lydenswerklikheid, maar elkeen belig belangrike aspekte van die evangelie van Jesus Christus.

\section{Frances Margaret Young (1939-) Lewensverhaal}

Frances Young is in 1939 as lid van 'n voorstedelike gesin in Engeland gebore. Haar vader was 'n skoolhoof en onder sy aanmoediging het sy 'n graadkursus in klassieke studies aan die Bedford Kollege, Universiteit van Londen, voltooi. Daarna studeer sy teologie aan die Universiteit van Cambridge. In 1970 behaal sy 'n doktorsgraad in Patristiek aan die Universiteit van Cambridge. Sy aanvaar in 1971 'n lektorspos in die Nuwe Testament aan die Universiteit van Birmingham. Young was werksaam aan die Universiteit van Birmingham vanaf 1971 tot en met haar aftrede in 2005. In dié tyd het sy poste beklee as lektor, senior lektor, professor, hoof van die Departement Teologie, dekaan van die Fakulteit Geesteswetenskappe en adjunk-visekanselier van die universiteit. Sedert 2006 is sy emeritusprofessor en steeds betrokke by navorsing en openbare lesings oor die Nuwe Testament en die Patristiek.

Die Universiteit van Cambridge het 'n besondere betekenis vir Young. Albei haar ouers het dáár gestudeer en gesamentlik besluit om hulppredikers in die Metodistekerk te word. Haar man, Bob, 
het ook aan Cambridge gestudeer, nou wel nie in teologie nie, maar in die natuurwetenskappe. Frances en Bob het as studente in Cambridge getrou en drie seuns is uit die huwelik gebore. Hulle eersteling, Arthur, is met erge liggaamlike en verstandelike gestremdhede gebore, en dit het 'n groot invloed op Young se verstaan van teologie gehad. Die ander twee seuns is verstandelik begaafd en ook produkte van die Universiteit van Cambridge.

Frances het grootgeword in die Metodistekerk en kan dus beskou word as 'n 'tweedegeslag-teoloog'. Albei haar grootvaders het teologie gestudeer en was predikante in die Metodistekerk. Aangevuur deur haar studie van die Patristiek, het sy 'n besondere belangstelling ontwikkel in die eksegese van Skrifgedeeltes waaraan die patristiese vaders aandag gegee het - met die bedoeling om die waarde daarvan vir die eie tyd te ontsluit. Sy het verskeie artikels en boeke daaroor gepubliseer (kyk veral na ed. Young, Ayres \& Louth [2004] 2010a en Mitchell \& Young 2008 vir haar bydraes in die hermeneutiek).

Frances Young word beskou as 'n pionier in die teologie van gestremdheid. Met die geboorte van Arthur in 1968 het sy'n lewenslange opgawe aanvaar om gestremdheid teologies te deurdink. Sy het 'n intense belangstelling in die werk van Jean Vanier (kyk o.a. Vanier 1992; 2005) ontwikkel, en het betrokke geraak by die versorging van persone met gestremdheid in instellings en gemeenskappe soos die L'Arche en die Foi et Lumière wat in Frankryk ontstaan het en tans in verskeie lande satellietinrigtings het. In hierdie gemeenskappe woon persone met gestremdhede nie in afsondering nie, maar saam met mense wat nie gestremd is nie. Sy het op uitnodiging deelgeneem aan die Faith and Light-pelgrimstogte na Lourdes, en het dikwels by kongresse referate gelewer oor teologie en gestremdheid. Sy het in 2011, as emeritus, met 'n reeks lesings aan die Universiteit van Oxford begin, wat bekend staan as die 'Bampton lectures'. In hierdie lesings het sy al die aspekte van haar lewe - as akademikus, predikant, en ma van 'n kind met erge gestremdhede - saamgevat in teologiese besinnings. Die temas waaraan sy aandag gegee het, sluit in: 'n Teologiese interpretasie van die skepping, die Christelike verstaan van menslike lewe, die persoon en werk van Christus, die vergewing van sondes en die drie-enige God. Die lesings is in 2013 gepubliseer in haar boek God's presence: A recapitulation of early Christianity.

Die uitdagings in die versorging van 'n kind met erge gestremdhede het elke aspek van haar persoonlike, kerklike en akademiese lewe beïnvloed. Dit was daarom óók n bepalende faktor in haar besluit om tot die bediening toe te tree. Frances was in 1984 met haar ordening as predikant reeds 'n heeltydse dosent. Alhoewel sy baie graag in die voetspore van haar grootouers en ouers wou volg om by die bediening betrokke te wees, was sy deeglik bewus van die uitdagings wat dit aan haar sou gestel het. Sy en haar man het met Arthur se geboorte besluit dat hulle hom tuis sou versorg en net van dagsorg by 'n inrigting gebruik sou maak om dit vir hulle moontlik te maak om ook met hulle akademiese loopbane voort te gaan. Met haar man se ondersteuning is sy georden as predikant, en het sy'n vrugbare bediening begin, toegespits op ander mense in moeilike lewensomstandighede. Sy het dikwels opgemerk dat haar lewe met Arthur en die uitdagings wat sy as gevolg daarvan moes hanteer, haar bevoorregte toegang tot die kernwaarhede van Christenskap gegee het.

Young is deur die koningin van Groot-Brittanje vereer met die Orde van die Britse Ryk vir haar bydrae tot die ontwikkeling van die teologie. Haar verkiesing tot lid van die Britse Akademie is erkenning van haar groot bydrae as akademikus. Frances was ook bevoorreg om in 2005 die eerste vrou en ook die eerste predikant van die Metodistekerk te wees wat'n openingsrede by die sinodesitting van die Kerk van Engeland (Church of England) kon lewer.

\section{Belangrike momente in Young se lewe}

- 1939 Geboorte

- 1971-1982 Lektor aan die Universiteit van Birmingham

- 1982-1986 Senior lektor aan die Universiteit van Birmingham

- 1984 Bevestig as predikant in die Metodistekerk

- 1986-2005 beklee die Edward Cadbury-professoraat in teologie en hoof van die Departement Teologie aan die Universiteit van Birmingham

- 1995-1997 Dekaan van die Fakulteit Geesteswetenskappe aan die Universiteit van Birmingham

- 1998 Ontvang die Orde van die Britse Ryk vir haar bydrae tot teologie

- 1997-2002 Adjunk-visekanselier van die Universiteit van Birmingham

- 2004 Verkies as lid van die Britse Akademie

- 2006 Emeritusprofessor aan die Universiteit van Birmingham

\section{Young se bydrae tot Reformatoriese teologie: 'n Oorsig}

Young het met haar bydrae 'A cloud of witnesses' in die boek van John Hick, The myth of God incarnate (1977), 'n opskudding veroorsaak omdat dit geïnterpreteer is as 'n aanval op die tradisionele verstaan van die menswording van Jesus. Dit het ondersteuners van die tradisionele voorstelling van Jesus se inkarnasie erg ontstel. Sy is egter heeltemal verkeerd verstaan. Haar argument was dat daar in die Vroeë Kerk nie net één voorstelling en verstaan van Christus se menswording was nie. Daar was verskillende uitlegtradisies, elk gekoppel aan 'n eie verstaan van soteriologie. In die 20ste eeu moes teoloë hierdie waarheid opnuut interpreteer sodat dit nuwe geloofwaardigheid kon wek. Sy was daarom verplig om deel te neem aan die opvolgpublikasie, onder redaksie van Michael Goulder, Incarnation and the myth (1979), waarin sy dit duidelik gestel het dat die menswording van Christus nie 
aan 'n eenduidige interpretasie gekoppel kan word nie. Die mens beskik oor 'n beperkte woordeskat en neig daarom om die menswording van Jesus te beskryf in terme van die beperking van die menslike verstand. Daarteenoor behoort die studie en bespreking van Jesus se geboorte, kruisiging, dood en opstanding eerder te fokus op God wat deur Jesus die wêreld met Hom versoen het. Frances het dit duidelik gestel dat sy oortuig was dat God Homself deur Jesus aan mense geopenbaar het as 'n lydende God en dat sy lyding gesien behoort te word as die gebeure wat die saligmaking van mense deur die vergewing van hulle sondes tot gevolg het. Deur te veel klem op die menswording van die opgestane Jesus te plaas, word die sentrale boodskap van die kruisiging afgewater. Hierdie opinie het sy later aangepas in From Nicaea to Chalcedon (1983) en The making of the creeds ([1991] 2007a), deur toe te gee dat sy deur verdere studie van die geskrifte van die vroeë kerkvaders tot ander insigte gekom het (vgl. Young 2005). Sy het groter begrip gekry vir die belangrikheid van die metafisiese beskrywing van die menswording van Jesus. Sy het ook toegegee dat hierdie ontologiese denke oor die inkarnasie van belang is vir die Christelike geloof, alhoewel dit vandag moeilik begryp word.

In haar boek The making of the creeds ([1991] 2007a) verduidelik Frances die ontstaan van geloofsbelydenisse. Kerkleiers het dokumentasie nodig gehad om lidmate te onderrig aangaande die verlossing van sonde en die heilige Drieeenheid, en het daarom opsommings gemaak van inligting rakende hierdie geloofsaspekte. Dit is ook die rede hoekom die geloofsbelydenisse aanvanklik van mekaar verskil het. Verskillende persone het dit saamgestel en dit is in verskillende gemeentes gebruik. Die geloofsbelydenisse is daarom nie abstrakte teologiese inligting nie, maar veel eerder die resultaat van 'n daadwerklike poging om die evangelie van die verlossing van sondes in 'n verskeidenheid van kontekste te verduidelik.

Die boeke Face to face: A narrative essay in the theology of suffering (1990) en Arthur's call: A journey of faith in the face of severe learning disability (2014) gee die geloofswroeging van Frances weer ná Arthur se geboorte en gedurende sy lewenslange versorging. Sy keer daarin terug na die geloofsaspekte wat sy in haar eerste publikasies aangeraak het, naamlik die lydende God en saligmaking deur die verlossing van sondes deur die kruisiging van Jesus. Sy verklaar dat dit vir Christene wat lyding ervaar, noodsaaklik is dat hulle kan weet dat God lyding oorkom het. Hy het nie die lydende gebly nie. Wanneer lydende mense net vaskyk teen hulle eie lyding, asook dié van God, ontvang hulle nie die troos dat lyding oorkom kan word nie. Dit maak ook nie saak dat groot getalle mense God se lyding deur Jesus se kruisiging verwerp nie, aangesien gelowiges wel verlossingswerk van Jesus Christus kan begryp en waardeer. Vir Young is dit belangrik om te glo dat ook persone met erge gestremdhede deur Jesus se kruisdood verlossing van hulle sondes ontvang het (sondevergewing is vir haar die oorkoepelende term vir die verskillende aspekte van die soteriologie). Hoewel daar in God se skepping tragedies soos die geboorte en lyding van mense met gestremdhede plaasvind, verlos God ons daarvan deur die kruisdood van Jesus (Young 1990:74; 2014:114).

In Brokenness and blessing: Towards a Biblical spirituality (2007b) gee Frances aandag aan haar eie ervaringe van swaarkry in 'n gebroke onvolmaakte werklikheid. Die vroeë kerkvaders verwys dikwels na die woestyn as 'n plek van swaarkry, maar ook as 'n plek waar Christene God ontmoet, vandaar die verwysing na 'woestynspiritualiteit'. Frances stel die woestyn van swaarkry van die Vroeë Kerk gelyk aan die swaarkry van gelowiges in die 21ste eeu en ook haar eie swaarkry as ma van 'n kind met erge gestremdhede. Net soos dit die geval was in die tyd van die Vroeë Kerk, bied swaarkry aan mense in hierdie eeu ook die geleentheid dat hulle deur die sinvolle verwerking van swaarkry God sal ontmoet. Sy staan 'n spiritualiteit voor wat aan mense die geleentheid bied om 'n realistiese perspektief van hulle wêreldse uitdagings te kry en om ook die wonder van 'n ontmoeting met God te beleef (Young 2007b:35).

\section{Publikasies waarna nie verwys word nie}

- 1975 Sacrifice and the death of Christ

- 1993 Virtuoso theology: The Bible and interpretation

- 1994 Theology of the pastoral letters

- 1995 Dare we speak of God in public?

- 1997 Biblical exegesis and the formation of Christian culture

- 2012 Theology and exegesis

Frances Young was ook die redakteur van volumes 39 tot 43 van die Studia Patristica.

\section{Young se nalatenskap}

Die blywende nalatenskap van die werke van Frances Young is haar beskouing van lyding met betrekking tot die skepping en die Kruisgebeure. Dit was vir haar aanvanklik baie moeilik om in 'n 'goeie God' met sy 'goeie skepping' te glo, te midde van die tragedie van menslike gestremdheid. Sy het geworstel met die gedagte dat die skepping van 'n God van liefde lyding insluit. In haar studie het sy tot die slotsom gekom dat geloof in God nie 'n ontsnappingsmeganisme uit die werklikhede van die wêreld is nie en dat die Christelike geloof menslike lyding nie verdoesel nie. Daarom kan teologie ook nie vrae oor die onvolmaaktheid van die skepping, en meer spesifiek die vraag na gestremdheid as deel van die skepping, vermy nie (Young 2013:3).

Die onvolmaaktheid van die skepping, soos vergestalt in die geboorte van mense met gestremdhede en hulle gepaardgaande lyding, herinner mense aan die broosheid van die skepping, asook hulle eie weerloosheid.'n Natuurlike reaksie is om alle hoop op die mediese wetenskappe te plaas, met die verwagting dat dit herstel en genesing kan bring. Moderne mense glo dat die mediese wetenskappe lyding kan versag en selfs die lewe kan verleng. Mense leef gevolglik vandag met die basiese veronderstelling dat onvolmaaktheid en lyding slegs tydelike terugslae is wat mettertyd 
'reggedokter' kan word. Die wêreld is dus eintlik goed en volmaak en gestremdheid in der waarheid 'niks' nie (Young 2007b:24). Menslike gestremdheid het dus nie plek in die openbare lewe nie, maar word na hospitale verskuif waar genesing kan plaasvind. Wanneer heling nie moontlik is nie, soos in die geval van persone met ernstige gestremdhede, is daar permanente institusionele versorging, wat die lyding uit die oog van die samelewing kan neem (Young 2007b:70).

Wanneer mense noodgedwonge deur gestremdheid gekonfronteer word, word die belewenis daarvan versag wanneer 'n rede daarvoor gevind kan word. Hierdie denke is nie net beperk tot ons huidige samelewing nie. In Johannes 9 vra Jesus se dissipels vir hom of die sonde van die ouers van die man wat van blindheid genees is, of sy eie sonde veroorsaak het dat hy blind is. In vers 3 van Johannes 9 antwoord Jesus: 'Nóg hy, nóg sy ouers het gesondig; maar dit het gebeur sodat die dade van God in hom geopenbaar kan word'. By die lees van hierdie vers lyk dit asof die man blind gebore is sodat God se dade geopenbaar kon word. Dit wil voorkom asof die man blindheid moes verduur sodat God hom gesond kon maak en mense wat dit sien tot bekering kan kom (Young 1990:73).

Beide die vraag of die man se blindheid veroorsaak is deur sy of sy ouers se sonde, sowel as Jesus se antwoord dat die man blind is sodat God se dade sigbaar kan word, het Frances as ouer van 'n gestremde kind ontstel. Dit was vir haar moeilik om te aanvaar dat daar mense is wat reken dat God kinders met gestremdhede gebore laat word om mense vir sondes te straf. Dit was vir haar ook moeilik om te aanvaar dat Jesus te kenne gee dat God mense met gestremdhede skape om hulle te gebruik om ander mense deur wonderwerke tot bekering te laat kom. Deeglike eksegese laat blyk egter dat dit nie die geval is nie. In Johannes 9 word die onvolmaakte skepping ('n man met gestremdheid) en die Kruisgebeure met mekaar verbind. Die blindheid van die man is sprekend van die 'donker' wat deur Jesus verlig sou word. Dit gaan dus nie oor die genesing van die man nie, maar oor die lig wat Jesus na die donker bring. In Johannes 9 vers 5 word daarna verwys: 'So lank as wat Ek in die wêreld is, is Ek die lig vir die wêreld'. Volgens die Johannes-evangelie word die Lig eers volledig na die wêreld gebring deur die Kruisgebeure waartydens Jesus die donker vir altyd weggeneem het. Die geloof dat God in Christus ons van die boosheid van die wêreld verlos het, is baie belangriker as 'n geloof in die goedheid van die skepping, wat ongelukkig deur gebrokenheid bederf word (Young 2014:104).

Die teodiseeprobleem, naamlik die vraag hoe jy die bestaan van 'n almagtige en liefdevolle God regverdig in die lig van die lyding en boosheid in sy skepping, word minder belangrik wanneer gelowiges besef hoe belangrik die Kruisgebeure is. Dit is dan nie nodig om lyding weg te redeneer nie of om die skepping van mense met gestremdhede deur God goed te praat deur redes daarvoor te vind nie. Gelowige ouers van kinders met gestremdhede kan aan die boodskap van die kruis vashou. God het sy Seun Jesus Christus gestuur na 'n wêreld van lyding sodat Hy dit op Hom kon neem; daarvoor verantwoordelikheid kon aanvaar sodat ons daarvan verlos kan word. Om lyding te verklaar, bring tydelike verligting. Aan die kruis is lyding permanent verwyder (Young 2013:138; 2014:119).

Die lyding van Jesus aan die kruis kan egter nie los van die lyding in die skepping bedink word nie. Enersyds is daar ' $n$ verband tussen die lyding van die gebroke werklikheid en menslike sonde. Selfs die kruisiging hou ook verband met menslike sonde. Die tragiek van die lewe is dat mense soms ly weens ander se sonde. Aan die ander kant het lyding dikwels niks te make met menslike daadsondes nie. Daar bestaan geen direkte verband tussen 'n gestremde kind en menslike sondes nie. In die lig hiervan bevind mense hulle in 'n situasie van 'duisternis'. Die onverklaarbaarheid van die onvolmaakte lewe skep 'duisternis' in mense se gemoed en daaglikse bestaan. Dit is binne hierdie konteks dat Young Jesus en sy kruis as die boodskap van 'lig' waardeer. Die boodskap van 'lig' wat oorkoepelend tot uiting kom in die boodskap van 'sondevergewing', is Young se troos (Young 2014:121).

Volgens Young is die kruisiging ook 'n 'tragedie'. Aan die kruis ly 'n onskuldige, en sy lyding is veelkantig. Jesus is verwerp deur mense. Hy is veroordeel deur mense. Hy is tot die dood aan 'n kruis gevonnis. Hy moes 'n dood van skande sterf. Dit wat Jesus oorgekom het, verteenwoordig wat alle mense die meeste vrees, naamlik verwerping, alleenheid, lyding en die dood. Jesus wat ons vrees deurgemaak het, neem nie net ons vrese weg nie. Hy verlos ons van ons sonde wat ten diepste met hierdie vrese verband hou. God keer negatiewe gebeure, naamlik sonde en lyding, om in die positiewe, naamlik die verlossing van sondes en die beëindiging van lyding. Jesus moes sterf sodat ons sondes vergewe kan word - en dít is die ware verlossing van ons lydensbestaan (Young 2013:108).

Volgens Frances hou die tragedie van die kruisiging die belofte in dat die tragedies van die wêreld, selfs ook die tragedie van 'n lewe van hulpeloosheid en weerloosheid van iemand met ernstige verstandelike en liggaamlike gestremdhede omgekeer kan word tot positiewe belewenisse. Die antwoord op ons vrae oor sonde, boosheid en lyding vind ons in die kruising van Jesus Christus. God, die Skepper, antwoord op lyding in sy skepping deur die kruisiging van sy Seun. Die geboorte van kinders met ernstige gestremdhede is deel van God se skepping, maar die ouers van hierdie kinders kan weet dat God in en deur die kruis 'lig verskaf' op die 'duisternis in hulle lewe'. Erg gestremde mense is deel van God se skepping en só ook deel van die sonde van die wêreld. Vir hulle sonde is ook aan die kruis betaal, al kan hulle dit met hulle beperkte verstandelike vermoë nie begryp nie (Young 2010b:99). Die merkwaardige is dat Frances Young, as 'n teoloog uit die Engelse Metodisme, dieselfde argument aanvoer as Martin Luther. Alreeds in 1518 het Luther (LDStA 1, 2006:54) in die Heidelbergse disputasie die gangbare theologia gloriae verwerp en dit met' $n$ theologia crucis vervang, aangesien 'God slegs in lyding en die kruis gevind kan word'. Filosofiese spekulasie (aldus Luther) bied geen 
werklike insig in lyding nie, en bowenal geen troos nie. Ons enigste hoop is die kruis en die genade van Christus.

\section{Dorothee Sölle (1929-2003) Lewensverhaal}

Dorothee Sölle is 'n sistematiese, politieke, sosiaal betrokke (publieke) en mistieke teoloog wat op 30 September 1929 in Keulen, Duitsland, gebore is. Met die uitbreek van die Tweede Wêreldoorlog, het haar ouers Hitler se rasse-ideologie privaat verwerp, maar nie by die amptelike weerstandsbeweging aangesluit nie (Wind [2009] 2012:15). Haar vader was 'n professor in arbeidsreg en hy het nominale openbare ondersteuning aan die Nazi-party gegee om sy gesin te beskerm. Die gesin het egter 'n Joodse vrou in hul huis se solder versteek (Sölle [1995] 1999:12) en ook die Joodse afkoms van Dorothee se ouma aan moederskant verberg. Later het haar onskuld te midde van haar ervaring om in 'n geleerde en gemaklike omgewing te midde van die Joodse volksmoord groot te word, in ontnugtering verander toe haar gesin gedwing is om hulle huis te verlaat te wyte aan die bombardement deur die Geallieerde weermag. As jong volwassene is sy vir die eerste keer deur die medepligtigheid van haar vader se generasie aan die Joodse volksmoord in die gesig gestaar. Dit het meegebring dat sy 'n stem sou word vir die mense van die Derde Wêreld en enige ander mense wat om selfbeskikking veg (kyk Cloyes DioGuardi 2013:177; vgl. Wind [2009] 2012:16-21).

Die ontwikkeling van Dorothee Sölle se lewe en teologie kan hoofsaaklik teen die agtergrond van die Joodse volksmoord geïnterpreteer word. In 1946, na afloop van die Tweede Wêreldoorlog, worstel sy met die 'niksheid' en die toestand van 'Geworfensein' (om te voel asof jy gegooi is) van die Duitse volk (Sölle [1995] 1999:24-25; Wind [2009] 2012:24). Sy het 'n groot gedeelte van haar lewe 'n innerlike stryd gehad oor die wyse waarop die Duitse Protestantse kerk (en die ortodokse Christelike religie van haar tyd) volledig aan Hitler toegegee het (Sölle [1995] 1999:25). In haar outobiografie, 'Gegenwind. Erinnerungen' (Against the wind: Memoir of a radical Christian), beskryf sy haar verhouding met die 'Christendom' as krities liberaal (Sölle [1995] 1999:26). In 1949 begin sy klassieke filosofie aan die Universiteit van Keulen studeer, maar vind nie daarin iets 'om van te lewe' nie (Sölle [1995] 1999:26). Sy begin 'n soektog na 'n outentieke vorm van lewe (Wind [2009] 2012:31-37) en besluit om teologie te bestudeer sodat sy die 'waarheid kan ontdek' wat lank genoeg van haar af weggehou is (Wind [2009] 2012:xi). In 1951 neem haar doktorale studie 'n aanvang. Die studie handel oor die verhouding tussen teologie en poësie en word onder die begeleiding van professor Friedrich Gogarten aangepak. Teologie, nie die kerk nie, het vir Sölle'n geestelike tuiste geword. Sy vind haar weg op 'n onkonvensionele wyse en uiteindelik haar tuiste in 'n nietradisionele, eksistensiële Christelike geloof, waarin dit belangrik is om jou eie taal en woorde te vind om oor God of Christus te praat (Sölle [1995] 1999:37), en nie die taal wat aan jou 'oorgelewer' is nie. Dit is 'n verwysing na die religieuse taal van die teologiese regverdiging/ondersteuning van die
Joodse volksmoord waarmee sy geworstel het en was die eerste stappe in haar ontwikkeling as politieke teoloog.

Die ander aspek wat 'n bewese invloed op haar teologie gehad het, is die wyse waarop sy haar geslag of gender beleef het as 'n 'agterstand' en teleurstelling ten opsigte van die bevoorregte posisie wat seuns en mans in die samelewing van haar tyd geniet het (vgl. Sölle [1995] 1999:11-15, 28-29; vgl. Sölle 1984:106-117). Die agterstand was veral vir haar wesenlik ten opsigte van die moontlikhede tot 'avontuur' wat in die verskillende loopbane vir mans beskore was, maar vir vroue was daar bloot 'die avontuur van moederskap' (Wind [2009] 2012:15). Sy het van 'n vroeë ouderdom af buite die konvensie en voorgeskrewe rolle vir die vroue van haar tyd opgetree (Grey 2005:344).

$\mathrm{Na}$ afloop van haar doktorale eksamen wat sy in 1954 suksesvol afgelê het, het sy as onderwyseres by 'n hoërskool vir meisies lesings oor religie aangebied. In haar lesings was sy krities ten opsigte van nasionaal-sosialisme, maar een van haar leerlinge het 'n keer opgemerk dat die Nazi's 'nie so erg was nie - hulle het die Autobahn gebou' (Sölle [1995] 1999:41). Haar lesings was só ontwerp om aan die leerlinge die krities politieke funksie van religie aan te toon. In 1964 begin sy die Politisches Nachtgebet [politieke naggebede] organiseer, wat as 'n gespreksforum ontstaan het vir Protestantse en RoomsKatolieke gelowiges om die verband tussen geloof en politiek prakties te laat realiseer (Sölle [1995] 1999:59-72; Wind [2009] 2012:37). Die groep wou 'n liturgie van gebed oor huidige politieke kwessies aanbied. Die toestemming is verkry, maar die liturgie is eers geskeduleer vir 23:00 en dit is hoe die 'aandgebede' 'n naam verkry het. Die benadering tot die byeenkomste was 'stryd en kontemplasie' (lute et contemplation) - 'n benadering wat ook aan die ekumeniese Taizè-klooster in Frankryk gevolg is. Tydens die byeenkomste is inligting deurgegee oor bepaalde wêreld- en politieke gebeure, terwyl die inligting deur die bespreking van Bybeltekste 'gekonfronteer' is. Dit is opgevolg deur'n oproep tot aksie. Die patroon van die aandgebede was dus: inligting, refleksie, aksie (Sölle [1995] 1999:60).

Tydens die aandgebed het die kwessies van die Viëtnamoorlog, die VSA se militêre ingryping in sekere wêrelddele en samelewingskwessies soos diskriminasie teen vroue veral aan die orde gekom. Groot getalle mense het die byeenkomste bygewoon. Trouens, in 1968 is in 'n Keulse koerant berig hoe die kerkgebou op die Schildergasse-straat net plek gehad het vir 300 mense en teen 20:30 was daar reeds meer as 1000 mense teenwoordig (Sölle [1995] 1999:61). Die politieke aandgebed was 'n ambivalente fenomeen vir die tyd waarin dit plaasgevind het. Die Viëtnamese oorlog is volgens haar eie beskrywing (Sölle [1995] 1999:72) die vernaamste rede vir haar radikaal demokratiese, politieke ingesteldheid. Sy het die Viëtnamese oorlog beskryf as 'n voortsetting van Auschwitz die Nazi-konsentrasiekamp. Die politieke aandgebede en haar protes (-optogte) teen die Viëtnamese oorlog sou die begin wees van talle anti-oorlogbewegings waarby sy betrokke was, wat in sommige gevalle tot arrestasie sou lei 
(1985) (vgl. Wind [2009] 2012:202). Haar teologie en haar politieke betrokkenheid het daartoe aanleiding gegee dat sy in Duitsland nooit 'n professoraat ontvang het nie (Cloyes DioGuardi 2013:196). In 1971 het sy haar ná-doktorale arbeid (Habilitation) voltooi en is sy van 1972-1975'n doseer-assistent by die Protestantse Fakulteit by die Universiteit van Mainz (Duitsland). Sy word egter professor in Sistematiese Teologie aan die Union Theological Seminary in New York waar ander teoloë soos Paul Tillich, Dietrich Bonhoeffer en Reinhold Niebuhr ook gedoseer het. Vier maande elke jaar van 1975-1987 het sy by Union klasgegee. Sy was 'n besoekende dosent aan die Universiteit van Basel van 1991-1992 en het in 1994 'n ereprofessoraat van die Universiteit van Hamburg ontvang. Tot en met haar dood in 2003 het sy die wêreld deurkruis as besoekende dosent en het sy vele lesings gelewer. Sy sterf op 27 April 2003 gedurende 'n naweekkongres in Göppingen, Duitsland.

\section{Sölle se bydrae tot Reformatoriese teologie: 'n Profetiese stem}

Die uitstaande kenmerk van Sölle se teologie is haar profetiese stem wat 'n unieke kombinasie van mistieke spiritualiteit en politieke weerstand is. Trouens, dit is haar mistieke spiritualiteit wat die basis is van haar politieke aktivisme omdat dit 'anti-outoritêr is' (kyk haar werk in 2001 getitel, Mystik und Wiederstand: 'Du stilles Geschrei', in Engels vertaal as 'The silent cry: Mysticism and resistance'). Mistieke ervaring is dié faktor wat eenheid bewerkstellig (eenheid met mekaar en met God), omdat dit 'demokraties' is en elke dag, enige dag met enigeen kan gebeur. Deur 'n verhouding met God word jy bevry van jou eie ego, van hebsug en van angs. Dit is volgens haar die beste voorbereiding wat jy kan kry om weerstand te bied teen'n wêreld waarin vermorsing plaasvind en 'n wêreld wat natuurlike hulpbronne opgebruik.

Sölle se politieke teologie het ontwikkel vanuit die 'God-is-dood'-beweging wat na die Tweede Wêreldoorlog momentum gekry het (Sölle [1965] 1967). Moltmann (2015:12) het haar in sy bydrae oor 'Europese politieke teologie' (vgl. Hovey \& Phillips 2015:3-15) beskryf as die mees profetiese stem van politieke teologie in na-oorlogse Duitsland (Moltmann 2015:12). Sy was die verteenwoordigende teoloog van groepe wat teen kernwapens, omgewingsvernietiging, kapitalisme en sosiale diktatorskap geprotesteer het. Dit was haar oortuiging dat teologie in staat moet wees om op haar eie sosiale en politieke situasie te kan reflekteer te midde van die konflik of krisis van die dag (Sölle 1971). Vir Sölle was 'politieke stryd' die enigste 'plek' om God te vind (Grey 2005:344). In hierdie opsig was teologie vir haar in die eerste plek nie 'n private aangeleentheid nie en gevolglik nie apolities nie. Na haar kennismaking met Latyns-Amerikaanse bevrydingsteologiehetsyhierdiewysevanteologiebeoefening as haar eie metode aangeneem. Later het Sölle haarself ook met die inhoud van feministiese teologie geïdentifiseer synde 'n teologie en 'n beweging wat gerig is op die ontmanteling van patriargale samelewingstelsels wat verhoed dat die totaliteit van die menslike bevolking gedy en lewenskwaliteit geniet. Alhoewel sy nie 'feministiese teologie' geskryf het in die sin dat sy uitsluitlik navorsing gedoen het op die gebied van die ontwikkeling van feministiese teorie nie (vgl. Grey 2005:345), het sy die rol van patriargie in 'die doodshandel' van onderdrukkende sisteme wêreldwyd beklemtoon (vgl. Radford Ruether 2003:205-217). Haar teologie is gekenmerk deur die beklemtoning van die rol wat sisteme speel in die instandhouding van bose regimes wat die lyding van mense veroorsaak. Oor vier dekades heen het sy kritiek jeens die kerk uitgespreek wat volgens haar nie in staat was om die verband te eien wat daar bestaan tussen die materiële ellende van die Derde Wêreld en die psigologiese ellende van die Westerse Wêreld op politieke, ekonomiese en sosiale gebied nie (Sölle [1975]1987). In haar kritiek het sy'n historiese bewussyn in teologie beklemtoon (Cargass \& Sölle 1988:123). Dit was vir haar byvoorbeeld ondenkbaar dat daar oor die verband tussen die Joodse en Christelike religieë gepraat kan word sonder verwysing na die Joodse volksmoord tydens die Tweede Wêreldoorlog.

As sistematiese teoloog het sy bygedra tot nadenke oor die klassieke loci (aspekte) van die dogmatiek. Sy het nie die starre dogmatisme of streng abstraksie van haar Duitse sistematies teologiese konteks aangeneem nie en was nie daarin gemaklik nie. Dit is een van die redes hoekom sy gemeen het dat sy as akademikus nie in die Duitse omgewing tereg gekom het nie (Grey 2005:346). Haar politieke teologie is egter juis haar reusebydrae tot sistematiese teologie in die vorm van die dekonstruksie van die klassieke Godsleer, veral gerig op die dekonstruksie van die klassieke verstaan van God se almagtigheid. In hierdie sin verstaan Sölle nie God se almag as 'afstand' en 'onbeweeglikheid' nie. In haar werk, Leiden (vertaal as Suffering) (Sölle [1973] 1975), lewer sy kritiek teen die gedagte dat God se almag die oorsaak van lyding is en dat mense vir 'n onbekende of groter doel moet ly. Sy het beklemtoon dat God saam met mense ly en dat die mensdom sáám stry teen onderdrukking, uitbuiting en gesagsvorme wat menslikheid ontneem (kyk Pinnock 2003). In hierdie opsig vertoon haar teologie ooreenkomste met die sistematiese én politieke teologie van twee Duitse teoloë, naamlik Johann Baptist-Metz en Jürgen Moltmann. Trouens, laasgenoemde het homself ook nie tuis gevoel in aspekte van sy Duitse abstrakte en 'stywe' teologiese omgewing nie (Moltmann [2006] 2008:137-138).

Die tydperk voor haar dood is haar teologie gekenmerk deur 'n terugkeer na die mistieke. 'Mistiek' vir Sölle is 'n 'verlange na God', die 'misterie' van die wêreld. Sy het geglo: '\#’n ander wêreld is moontlik' (Sölle [1999] 2001). Haar laaste en onvoltooide boek, Mystik des Todes (Mystery of death) ([2003] 2007), gaan oor die misterie van dood. Dit is nie'n verlange na dood nie, maar eerder verlange na 'n vol en vrye lewe in God. Dit is tekenend van haar vroegste soeke na 'iets om van te lewe' en 'n taal om God mee te beskryf. Haar teologie, synde misties en polities, is dialekties op 'n manier. Sy het tegelyk 'voor God neergebuig' en 'geleer om regop te loop' (Wind [2009] 2012:4). Hierdie woorde is uittreksels uit haar gedig 'Droom my, God' (Dream me, God) (Wind [2009] 2012:1) en is simbole van haar ervaring van die menslike toestand en haar 
geloof in die noodsaak van 'n herverbintenis tot God. Haar revolusionêre aktivisme en mistieke toewyding aan God het haar strewe na vrede gekenmerk.

\section{Nalatenskap en bydrae tot die Reformatoriese erfenis}

As beide digter en protesteerder is haar teologie praktykgerig en gegrond op ervaring.

Die erfenis van Dorothee Sölle as reformatoriese teoloog lê in die 'hervormende' karakter van haar teologie: Sy het die wisselwerking tussen individu en geloofsgemeenskap voortdurend getoets in die lig van eie en gemeenskaplike sekerhede wat tot nadeel van kerk en gemeenskap vertroetel kan word. Sy het teologiese weerstand gebied teen enige en alle vorme van onderdrukking en daarom is haar teologie 'n reformatoriese teologie - 'n teologie van reformatio mundi - 'n transformasie van alle aspekte van lewe volgens God se woord van lewe.

Sölle se teologie is reformatories ook omdat dit 'n kritiese teologie is: sy was krities teenoor die gebruik van God se woord van lewe om lewe te ontneem. Reformatoriese teologie is 'n teologie wat' $n$ konstante uitdaging aan gelowiges rig om krities en selfkrities op antitotalitêre wyse in elke ander tyd en nuwe situasie opnuut te onderskei wat God se waarheid beteken en hoe dit neerslag vind. Sy was oortuig dat 'God se hande' ons hande is en daardeur het sy gelowiges se daadwerklike betrokkenheid in en by die wêreld beklemtoon.

Sölle se teologie is mistiek spiritueel en is gekenmerk deur ' $n$ blywende hunkering na God en 'n oorgawe aan God en 'n voortdurende soektog na God in die wêreld. Sy het haar beywer vir vrede en 'n meer verdraagsame wêreld. Vir haar was lewensvervulling te vinde in'n diep spirituele verhouding met God.

Vir baie is sy 'n kontroversiële teoloog en haar aktivisme oor en solidariteit met gemarginaliseerdes is polities eerder as teologies (Grey 2005:344-345). Ander beskou haar as 'n spreekwoordelike Christelike profeet wat die grens tussen teologiese wetenskap en die werklikheid van die lewe (praktyk) tot niet gemaak het. Sy het weliswaar nie in konvensionele kategorieë geskryf nie (vgl. Grey 2005: 345; vgl. Wind [2009] 2012:1-5). Een van haar voormalige studente wat 'n redakteur van een haar boeke sou word, Shirley Cloyes DioGuardi (2013:197), beskryf Sölle as 'n Protestantse ekumeniese teoloog wat oor kontinente heen 'n dosent en onderwyser was.

Sölle se appèl tot kerk en teologie om die dors na geregtigheid en regverdigheid aan te spreek, is vandag geldig en dringend in 'n wêreld waarin die toenemende gaping tussen ryk en arm, omgewingsaftakeling en die onbeteuelde groei van militêre magte en die militêre industrie ervaar word en die eksistensiële gevolge van oorlog 'n vreesaanjaende algemene verskynsel geword het. Sölle se rol in verskeie vrede- en solidariteitsbewegings regoor die wêreld veertig jaar lank het 'n blywende indruk gemaak. In die biografie van Dorothee Sölle, beskryf Renate Wind ([2012] 2009) die karakter en invloed van Sölle soos volg:

One cannot speak of Dorothee Soelle without dreaming the dream that the world might yet be able to find its true order after all; that all Gods creatures might live together free of violence, without human beings or nature being destroyed; that life and work return to a human scale and that life in abundance would not be the luxury for the few that it now is, but possible for all, so that the Biblical Shalom might become reality, where justice and peace are united forever. (p. 1)

\section{Erkenning}

T.v.W. se navorsing en die befondsing van hierdie artikel is moontlik gemaak deur die ondersteuning van die SuidAfrikaanse Akademie vir Wetenskap en Kuns. Deur hierdie ondersteuning te bied word verseker dat Afrikaans as akademiese taal uitgebou word.

\section{Mededingende belange}

Die outeurs verklaar dat hulle geen finansiële of persoonlike verhouding(s) het wat hulle op 'n voordelige of nadelige wyse by die skryf van die artikel beïnvloed het nie.

\section{Outeursbydrae}

T.v.W. het die afdeling wat oor Dorothee Solle handel, nagevors en geskryf en N.C.v.W. het die afdeling oor Frances Young nagevors en geskryf.

\section{Literatuurverwysings}

Cargass, H.J. \& Sölle, D., 1988, 'Interview with Dorothee Sölle', Encounter 49(2), 123-128.

Cloyes DioGuardi, S, 2013, 'Mystic and rebel - The pathbreaking journey of Dorothee Soelle', Theology Today 70(2), 196-199, https://doi.org/10.1177/0040573613 485526

Goulder, M. (ed.), 1979, Incarnation and myth, S.C.M. Press, London.

Grey, M., 2005, 'Diversity, harmony and in the end, justice: Remembering Dorothee Soelle', Feminist Theology 13(3), 345-357, https://doi.org/10.1177/096673 5005054916

Hovey, C. \& Phillips, E., 2015, The Cambridge companion to Christian political theology, Cambridge University Press, Cambridge.

Luther, M., [1518] 2006, 'Disputatio Heidelbergae habita/Heidelberger Disputation', in W. Härle (Hrsg.) Martin Luther: Lateinisch-Deutsche Studienausgabe, Band 1 (LDStA 1), Der Mensch vor Gott, pp. 35-69, übersetzten und bearbeiten von W. Härle, Evangelische Verlagsanstalt, Leipzig.

Mitchell, M. \& Young, F. (ed.), 2008, The Cambridge history of Christianity. Volume 1. Origins to Constantine, Cambridge University Press, Cambridge.

Moltmann, J., [2006] 2008, Weiter Raum/Broad place, Fortress Press, Minneapolis, MN.

Moltmann, J., 2015, 'European political theology', in C. Hovey \& E. Phillips (eds.), Christian political theology, pp. 3-22, Cambridge University Press, New York.

Oliver, D.L., 2006, Dorothee Soelle: Essential writings, Orbis, Maryknoll, NY.

Pinnock, S.K., 2003, The theology of Dorothee Soelle, Trinity Press International, Harrisburg, PA.

Radford Ruether, R., 2003, 'The feminist liberation theology of Rosemary Ruether', in S.K. Pinnock (ed.), The theology of Dorothee Soelle, pp. 205-217, Trinity Press International, London.

Sölle, D., [1965] 1967, ${ }^{1}$ Stellvertretung. Ein Kapitel Theologie nach dem Tode Gottes/ Christ the representative: An essay in theology after the 'Death of God', Kreuz, Stuttgart.

Sölle, D., 1971, Politische theologie. Eine Auseinandersetzung mit Rudolf Bultmann, Political Theology. A critical reflection on Rudolf Bultmann, Kreuz, Stuttgart.

Sölle, D., [1973] 1975, Leiden/Suffering, Kreuz, Stuttgart.

1.'n Volledige lys van Dorothee Sölle se gepubliseerde werke verskyn in Oliver (2006). 
Sölle, D., [1975] 1978, Hinreise. Zur religiösen Erfahrung. Texte und Uberlegungen/The inward road and the way back, Kreuz, Stuttgart.

Sölle, D., 1984, The strength of the weak: Toward a Christian feminist identity, Westminster Press, Philadelphia, PA.

Sölle, D., [1995] 1999, Gegenwind. Erinnerungen/Against the wind: Memoir of a radical Christian, Hoffmann and Campe, Munich.

Sölle, D., [1999] 2001, Mystik und Wiederstand. 'Du stilles Geschrei'/The silent cry: Mysticism and resistance, Hoffmann and Campe, Hamburg.

Sölle, D., [2003] 2007, Mystik des Todes/Mystery of death, Kreuz, Stuttgart.

Vanier, J., 1992, From brokenness to community, Paulist Press, New York.

Vanier, J., 2005, Encountering 'the other', Veritas Publications, Dublin.

Williams, R., 2005, 'Profile: Frances Young', in R. Sugirtharajah (ed.), Wilderness: Essays in honour of Frances Young, pp. 1-7, T\&T Clark International, London.

Wind, R., [2009] 2012, Dorothee Sölle - Rebellin und Mystikerin. Die Biographie/ Dorothee Soelle - Mystic and Rebel. The biography, Fortress Press, Minneapolis, MN.

Young, F., 1977, 'A cloud of witnesses', in J. Hick (ed.), The myth of God incarnate, pp. 13-47, S.C.M. Press, London.
Young, F., 1983, From Nicea to Chalcedon, S.C.M. Press, London.

Young, F., 1990, Face to face: A narrative essay in the theology of suffering, T\&T Clark International, Edinburgh.

Young, F., 2005, "The "mind" of scripture: Theological readings of the Bible in the fathers', International Journal of Systematic Theology 7(2), 126-141. https://doi. org/10.1111/j.1468-2400.2005.00156.x

Young, F., [1991] 2007a, The making of the creeds, Third impression, SCM Press, London.

Young, F., 2007b, Brokenness and blessing: Towards a biblical spirituality, Darton, Longman and Todd Ltd., London.

Young, F., 2010b, 'The church as a learning community', in M. Hooker \& F. Young (ed.), Holiness and Mission, pp. 99-105, S.C.M. Press, London.

Young, F., 2013, God's presence: A contemporary recapitulation of early Christianity, Cambridge University Press, Cambridge.

Young, F., 2014, Arthur's call: A journey of faith in the face of severe learning disability, Society for Promoting Christian Knowledge (SPCK), London.

Young, F., Ayres, L. and Louth, A. (ed.), [2004] 2010a, The Cambridge history of early Christian literature, Cambridge University Press, New York. 